Przegląd Prawa Konstytucyjnego

-----ISSN 2082-1212-----

DOI 10.15804/ppk.2020.04.10

-----Nr 4 (56)/2020-----

Jacek Zaleśny ${ }^{1}$

\title{
Ustrojowe dysfunkcyjności przenoszenia oraz delegowania sędziów i asesorów sądów powszechnych jako przejaw ustawowo ustanowionego nadzoru Ministra Sprawiedliwości nad sądami powszechnymi
}

Słowa kluczowe: sądy powszechne, nadzór Ministra Sprawiedliwości, przenoszenie sędziów i asesorów sądowych, delegowanie sędziów i asesorów sądowych, dysfunkcjonalność ustrojowa

Keywords: common courts, supervision of the Minister of Justice, transfer of court judges and judge assessors, system dysfunctionality

\section{Streszczenie}

Celem artykułu jest zbadanie kompetencji Ministra Sprawiedliwości w zakresie przenoszenia i delegowania sędziów i asesorów sądów powszechnych. Dla jego realizacji wykorzystano metodę dogmatyczną. W artykule stawia się tezę, że kompetencje Ministra Sprawiedliwości w postaci przenoszenia i delegowania sędziów i asesorów sądów powszechnych sprzyjają nie tyle pielęgnowaniu w sędziach poczucia roztropności i starannego wymierzania sprawiedliwości, co wzmacniają żądzę awansowania, przyspieszonego podniesienia statusu społeczno-materialnego, przez co zawierają w sobie wysoki ładunek dysfunkcjonalności i jako takie w przypadku przenoszeń powinny zostać ograniczone, a delegacji - uchylone.

1 ORCID ID: 0000-0002-8231-4454, doktor habilitowany, Katedra Systemów Politycznych, Wydział Nauk Politycznych i Studiów Międzynarodowych, Uniwersytet Warszawski. E-mail: zalesnyjacek@gmail.com. 


\section{Abstract \\ Dysfunctionalities in the System of Transfer and Delegation of Judges and Associate Judges of Common Courts as a Sign of Supervision Exercised by the Minister of Justice over Common Courts and Established in Statute}

The purpose of the article is to examine the competences of the Minister of Justice in the sphere of transfer and delegation of judges and associate judges of common courts. To this aim the dogmatic method was applied. The article puts forward the thesis that the competence of the Minister of Justice in transfer and delegation of judges and judge assessors promotes not so much the nourishing of judges' sense of prudence and careful administration of justice as strengthening the desire to promote and accelerate a rise in the social and material status, thus containing a high burden of dysfunctionality, which as such should be revoked.

Na podstawy konstytucyjnie ustalonego ustroju sądów składają się ich odrębność i niezależność od innych władz (art. 173 Konstytucji RP). Przyjęte rozwiązanie prawne jest rozwinięciem i konkretyzacją zasady podziału władzy. Dodatkowo, przewiduje się (art. 10 Konstytucji RP) uzupełnienie podziału władzy o równowagę władz. Ustrój zrównoważony (łączący w sobie podział i równowagę władz) traktowany jest jako formalna gwarancja ochrony z jednej strony przed tyranią dyktatury, a z drugiej strony - przed nie mniej groźną dla zachowania wolności i praw jednostki - tyranią anarchii. Jak zwracał uwagę w trakcie prac nad konstytucją amerykańską Thomas Jefferson, ze względu na realizację wolności i praw jednostki te dwa ryzyka - ryzyko tyranii i ryzyko anarchii - należy rozpatrywać łącznie i łącznie przed nimi należy zabezpieczyć ustrój państwa.

Z punktu widzenia budowy rządów zrównoważonych, nie będących zagrożeniem dla urzeczywistniania wolności i praw jednostki, na różne sposoby można określać relacje zachodzące między legislatywą i egzekutywą (np. rządy parlamentarno-gabinetowe w ich licznych wariantach, rządy pre- 
zydenckie czy rządy zgromadzenia) ${ }^{2}$. Natomiast, jeśli chodzi o ustrojowe określenie pozycji sądów, to doktryna prawa nie dopuszcza podobnej swobody. Jednoznacznie zaznacza się w niej, że sądy mają być niezależne względem pozostałych władz. Zarazem, co wymaga zaznaczenia, poprzez art. 173 Konstytucji RP, w którym przesądza się, że sądy (i trybunały) są władzą odrębną i niezależną od innych władz, nie znosi się podstawowej zasady ustrojowej Rzeczypospolitej Polskiej: podziału i równowagi władzy ustawodawczej, wykonawczej i sądowniczej ${ }^{3}$. W żadnym też stopniu nie modyfikuje się jej. Jak orzekł Trybunał Konstytucyjny w wyroku z 18 lutego 2004 r. rozdzielone władze nie są niezależnymi od siebie elementami władzy państwowej. Składają się na jedną konstrukcję, w ramach której zobowiązane są współdziałać z sobą, aby w ten sposób realizować (przywołane w art. 1 Konstytucji RP) dobro wspólne wszystkich obywateli. Odrębność i niezależność sądów powszechnych nie mogą prowadzić do zniesienia czy ograniczenia równowagi zachodzącej między władzą ustawodawczą, wykonawczą i sądowniczą.

Niezależność sądów jest kanonem współczesnego konstytucjonalizmu, jak również jest kanonem współcześnie przyjmowanych czy rekomendowanych systemów prawnych, jak system prawny Rady Europy czy Unii Europejskiej. Jak pisał Monteskiusz w $O$ duchu praw, dziele, które pomimo upływu ponad 250 lat od jego powstania, wciąż jest uznawane za swego rodzaju puentę teoretycznych rozważań nad ustrojem zrównoważonym, „nie ma również wolności, jeśli władza sędziowska nie jest oddzielona od prawodawczej i wykonawczej. Gdyby była połączona z władzą prawodawczą, władza nad życiem i wolnością obywateli byłaby dowolna; sędzia bowiem byłby prawodawcą. Gdyby była połączona z władzą wykonawczą, sędzia mógłby mieć siłę cie-

2 Szeroko na temat przykładowych sposobów aranżowania relacji zachodzących między władzą ustawodawczą a władzą wykonawczą zob. np. Systemy rządów w perspektywie porównawczej, red. J. Szymanek, Warszawa 2014.

3 M. Mazurkiewicz, Problem zwierzchniego nadzoru nad działalnością administracyjna sądów na tle konstytucyjnych gwarancji niezależności sądów i niezawisłości sędziów, [w:] Transformacja systemów wymiaru sprawiedliwości. Tom I. Pozycja ustrojowa władzy sądowniczej i uwarunkowania transformacji, red. J. Jaskiernia, Toruń 2011, s. 521.

4 Sygn. akt K 12/03, http://prawo.sejm.gov.pl/isap.nsf/download.xsp/WDU20040340304/T/D20040304TK.pdf(28.01.2020). 
miężyciela”" O ile potrzeba niezależności sądów jest powszechnie akceptowana, o tyle nie jest jednakowo rozumiana. Zwrotowi „niezależność sądów” nadaje się rozmaity desygnat.

Niezależność sądów jest postrzegana przez wzgląd na cel, który ma ona realizować. Jest nim realizacja prawa do sądu ${ }^{6}$ poprzez sprawiedliwe i słuszne rozstrzyganie konfliktów prawnych, co ma prowadzić do realizacji wolności i praw jednostki, jak również zachowania równowagi w systemie podzielonej władzy. Niezależność wobec innych władz ma umożliwić sądom podejmowanie decyzji niepopieranych przez inne władze, ale mających umocowanie w obowiązujących przepisach prawa i sprawiedliwych. Mają stabilizować zachodzące stosunki prawne i ich interpretację, a w rezultacie - działać na rzecz stabilizacji i przewidywalności ustroju państwa. Z tego też powodu sądy powinny mieć zdolność przeciwstawienia się woli tych uczestników stosunków politycznych, którzy metodami niekonstytucyjnymi chcieliby dokonywać zmian prawnych. Niezależność sądów względem innych władz uznawana jest za formalną gwarancję obiektywizmu działania sądów, którego efektem ma być sprawiedliwe rozstrzyganie zawisłych spraw.

Od niezależności sądów odróżnia się, także w polskiej Konstytucji, niezawisłość sędziów. Jej waga ustrojowa wynika z charakteru władzy sądzenia. Ten, który rozstrzyga spór prawny, w sposób stanowczy przesądza o wolnościach i prawach innych, musi być bezstronny i profesjonalny w swojej działalności tak, aby uczestnicy stosunków prawnych nie mieli uzasadnionych wątpliwości co do motywów jego działania i sprawiedliwości podjętej decyzji. Bez niezawisłości sędziowskiej nie ma zaufania społecznego do sądu jako organu władzy zapewniającego realizację wolności i prawa jednostki, a przeciwnie - w tego typu stanie faktycznym, władza sądzenia może być traktowana jako przejaw represyjności władzy państwowej, która w sposób dowolny, w oderwaniu od obowiązującego stanu prawnego i aksjologii państwa prawnego, rozstrzyga o wolnościach i prawach jednostki. Bez zaufania do osoby

5 Monteskiusz, O duchu praw, s. 81, https://wolnelektury.pl/media/book/pdf/o-duchu-praw.pdf (25.01.2020).

6 A. Machnikowska, O niezawisłości sędziów i niezależności sądów w trudnych czasach. Wymiar sprawiedliwości w pułapce sprawności, Warszawa 2018, s. 33; A. Rakowska-Trela, Sądy i sędziowie wobec niedemokratycznych przemian, „Studia Politologiczne” 2018, vol. 47. 
sędziego, motywów i przejawów jego aktywności, władza sądzenia zatraca swój sens. Jest urzeczywistniana, ale towarzyszy jej poczucie przemocy instytucjonalnej, bezprawia tym bardziej dotkliwego, że realizowanego w imię wymierzania sprawiedliwości.

Zgodnie $\mathrm{z}$ art. 178 Konstytucji RP, sędziowie sądowi w sprawowaniu swojego urzędu są niezawiśli i podlegają wyłącznie prawu - tylko Konstytucji RP oraz ustawom. W związku z rzetelnym, obiektywnym, wykonywaniem czynności sędziowskich, sędziowie nie mogą obawiać się ani kary ani też liczyć na uzyskanie nagrody. Nie ma przy tym większego znaczenia, z czyjej strony miałyby mieć miejsce występujące oddziaływania ingerujące w tok sprawowania urzędu sędziowskiego: organów egzekutywy, legislatywy, mass mediów, uczestników sądowego postępowania czy organów sądu, jak prezes, kolegium sądu czy zgromadzenie ogólne sędziów. Trzeba także dostrzegać ryzyka związane z orzekaniem sędziów zgodnie z linią orzeczniczą sądów wyższej instancji czy też sądów i trybunałów pozakrajowych, jak Europejski Trybunał Praw Człowieka czy Trybunał Sprawiedliwości Unii Europejskiej. Nie jest wykluczoną sytuacja, że sędzia nie tyle sam dokonuje interpretacji przepisów prawa (zgodnie z kanonami jego wykładni), co kieruje się interpretacją dokonaną przez inny sąd, ze względu na jego pozycję w systemie organów władzy. Jeszcze inną jest sytuacja, w której w sporze $\mathrm{z}$ sądem czy trybunałem pozakrajowym jest rząd, a podjęte przez niego (tj. sąd czy trybunał pozakrajowy) orzeczenie oddziałuje na sprawę zawisłą przed sądem krajowym czy też sąd krajowy podejmuje decyzję w sprawie nadania klauzuli wykonalności orzeczeniu zagranicznego sądu polubownego.

Ze względu na swoją funkcję w postaci sprawiedliwego i słusznego sądzenia, niezawisłość sędziego jest podstawą dobrego ustroju i jako taka powinna promieniować na wszystkie akty stanowienia i stosowania prawa i odpowiednio - ze względu na nią z systemu prawnego państwa powinny być eliminowane rozwiązania prawne, które mogą negatywnie oddziaływać na zdolność sędziego do sprawiedliwego i słusznego orzekania i budowania przez to społecznego zaufania do sądów jako organów wymierzających sprawiedliwość.

W tej ustrojowej perspektywie należy poddać rozważeniu kompetencje, którymi dysponuje Minister Sprawiedliwości względem przenoszenia i dele- 
gowania sędziów i asesorów sądowych. Są one jednym z przejawów realizowanego przez Ministra nadzoru nad administracją sądową .

Jako organ władzy publicznej odpowiedzialny za organizacyjnie właściwe funkcjonowanie sądów, Minister Sprawiedliwości prowadzi politykę etatową w sądach co do obsady ilościowej sędziów i asesorów sądowych. Jest tym organem władzy publicznej, który decyduje o nasyceniu osobowym czynnika sędziowskiego (i asesorskiego) w sądach i jako taki wpływa na zdolność wykonywania przez sądy powierzonych im czynności bez zbędnej zwłoki. W tej samej grupie kompetencji Minister Sprawiedliwości decyduje o ustanowieniu i przyznaniu poszczególnym sądom etatów referendarzy sądowych i asystentów sędziów. Ma zatem możliwość dostosowania w poszczególnych sądach liczby etatów sędziowskich, asesorskich, referendarskich i asystenckich do powstałych potrzeb i tym samym stworzyć warunki dla realizacji praw obywatelskich w zakresie sprawnego wykonywania przez sądy powszechne powierzonych im obowiązków. W tej grupie ministerialnych kompetencji mieści się przenoszenie i delegowanie sędziów i asesorów sądowych.

Jedną z materialnych gwarancji niezawisłości sędziego jest pewność czyli stabilność ${ }^{8}$ stosunku służbowego. Sędzia powoływany jest przez Prezydenta RP do pełnienia urzędu sędziego w konkretnym sądzie. Istoty powołania osoby do pełnienia urzędu sędziego nie można redukować do wyrażenia zgody na wykonywanie przez nią kompetencji sędziego. Akt powołania zawiera w sobie znacznie dalej idące konsekwencje ustrojowe. Prezydencki akt powołania sędziego nie tylko legitymuje osobę do sprawowania władzy sądzenia, ale zarazem, co nie mniej ważne, określa zakres sprawowanej władzy sądzenia9 Sędzia nie jest powoływany do wymierzania sprawiedliwości in abstracto, czy też, nie uzyskuje zgody na pomaganie Ministrowi Sprawiedliwości w wykonywaniu jego kompetencji, ale sprawuje wymiar sprawiedliwości tylko w obrębie jednej, konkretnie wyznaczonej siedziby, o określonym zakresie jurys-

7 W pracy pomija się motyw konstytucyjności nadzoru Ministra Sprawiedliwości nad sądami powszechnymi.

8 Zob. G. Ławnikowicz, Z rozważań nad polskim autorytaryzmem. Pewność stanowiska sędziego w Konstytucji kwietniowej, „Annales Universitatis Mariae Curie Skłodowska Lublin Polonia” 2019, Sectio G, vol. LXVI, 1, s. 237.

9 A. Machnikowska, op.cit., s. 328. 
dykcji ${ }^{10}$, który jest określony w akt powołania przez Prezydenta RP. Oznacza to, że sędzia nie pełni służby w dowolnym sądzie, ale tylko w takim miejscu, które zostało mu ściśle wyznaczone przez Prezydenta RP, a tym bardziej nie jest powołany do pełnienia służby w Ministerstwie Sprawiedliwości, Kancelarii Prezydenta RP czy innej jednostce organizacyjnej. Sędzia jest uprawniony do orzekania wyłącznie w tym sądzie, do którego został powołany. Także z tego właśnie powodu sędzia nie może być swobodnie przenoszony do innej siedziby. Siedzibą sędziego jest bowiem konkretny sąd (obszar jurysdykcyjny), w którym sprawuje on wymiar sprawiedliwości. Sędzia otrzymuje od Prezydenta RP akt powołania do konkretnego sądu, a nie akt powołania na „jakieś" stanowisko sędziowskie, co pozwalałoby na jego przenoszenie między różnymi siedzibami ${ }^{11}$ czy też delegowanie do różnych instytucji.

Ustawodawca gwarantuje sędziemu, że dopóki rzetelnie wykonuje powierzone mu obowiązki dopóty pozostanie sędzią danego sądu. Wszelkie odstępstwa od tej zasady, jako mające charakter wyjątku, mogą wynikać wyłącznie z przepisów ustawy i być zgodnie z przepisami Konstytucji RP. W tym też zakresie powinny być konfrontowane $\mathrm{z}$ istotą sądzenia i zasadą budowania społecznego zaufania władzy sądowniczej.

Pewności służby sędziego nie można redukować do nieusuwalności sędziego. Należy rozumieć ją znacznie szerzej, jako stabilność piastowania służby w ramach określonego stosunku służbowego w konkretnym sądzie, wskazanym w prezydenckim akcie powołania na sędziego. Składowymi tak rozumianej pewności stosunku służbowego są m.in. nieprzenoszalność sędziego na inne miejsce służbowe oraz zakaz delegowania go na inne miejsce służbowe.

W gestii Ministra Sprawiedliwości nie leży przydział czynności poszczególnym sędziom. Jest to kompetencja prezesa sądu, wykonywana po zasięgnięciu opinii kolegium danego sądu (w przypadku prezesa sądu rejonowego - kolegium właściwego sądu okręgowego). Minister nie jest zatem organem właściwym do przydzielania sędziów, asesorów sądowych i referendarzy sądowych do wydziałów sądu. Nie wyznacza zakresu obowiązków sędziów, asesorów sądowych i referen-

10 W. Kozielewicz, Instytucja delegowania sędziego do petnienia obowiązków sędziego w innym sądzie - aspekty ustrojowe i procesowe, [w:] Rzetelny proces karny. Księga jubileuszowa Profesor Zofii Świdy, red. J. Skorupka, Warszawa 2009, s. 183.

11 Wyrok Sądu Najwyższego z 25 stycznia 2016 r., III KRS 48/13, http://www.sn.pl/ sites/orzecznictwo/Orzeczenia3/III\%20KRS\%2048-13.pdf (26.01.2020). 
darzy sądowych i sposobu ich uczestniczenia w przydziale spraw. Nie określa planu dyżurów oraz zastępstw sędziów, asesorów sądowych i referendarzy sądowych.

Przeniesienie sędziego i asesora sądowego do innego wydziału sądu jest kompetencją prezesa sądu, na której wykonywanie Minister nie ma wpływu. Minister uczestniczy natomiast w przenoszeniu sędziego na inne miejsce służbowe. Wydaje decyzję o przeniesieniu sędziego na inne miejsce służbowe. Co do zasady, odbywa się ono tylko za zgodą sędziego. Zgodnie z obowiązującymi przepisami, wydając decyzję co do wniosku sędziego o przeniesienie na inne miejsce służbowe, Minister Sprawiedliwości kieruje się racjonalnym wykorzystaniem kadr sądownictwa powszechnego, potrzebami wynikającymi z obciążenia zadaniami poszczególnych sądów, a także okolicznościami wynikającymi z uzasadnienia wniosku.

Jedynie w sytuacjach wyjątkowych przeniesienie sędziego na inne miejsce służbowe nie wymaga zgody sędziego. Sytuacja taka ma miejsce w przypadkach ustawowo wyliczonych. Są one następujące:

- zniesienie stanowiska służbowego wywołane zmianą w organizacji sądownictwa lub likwidacją danego sądu lub wydziału zamiejscowego albo przeniesieniem siedziby sądu;

- niedopuszczalność zajmowania stanowiska sędziego w danym sądzie wskutek wystąpienia okoliczności kolizyjnych;

- gdy wymaga tego wzgląd na powagę stanowiska, to przeniesienie odbywa się na podstawie orzeczenia sądu dyscyplinarnego, wydanego na wniosek kolegium właściwego sądu lub Krajowej Rady Sądownictwa;

- przeniesienie w wyniku kary dyscyplinarnej.

W przypadku zniesienia stanowiska służbowego wywołanego zmianą w organizacji sądownictwa lub likwidacją danego sądu lub wydziału zamiejscowego albo przeniesieniem siedziby sądu, przeniesienie sędziego na inne miejsce służbowe może nastąpić dopiero wtedy, jeżeli nie jest możliwe uwzględnienie wniosku sędziego co do nowego miejsca służbowego. In concreto istnieć musi związek logiczny między reorganizacją sądów a przeniesieniem konkretnego sędziego. Zmiana w organizacji sądów czyni przeniesienie koniecznym. W przeciwnym wypadku mogłoby dojść do naruszenia pewności stosunku służbowego sędziego.

W pierwszych dwóch przypadkach przeniesienia sędziego na inne miejsce służbowe od decyzji Ministra Sprawiedliwości sędziemu przysługuje odwo- 
łanie do Sądu Najwyższego. Do postępowania odwoławczego przed Sądem Najwyższym stosuje się przepisy Kodeksu postępowania cywilnego o skardze kasacyjnej, z wyjątkiem regulacji o przymusie adwokacko-radcowskim.

W praktyce dochodzi do przenoszenia sędziów na inne miejsce służbowe ze względu na zniesienie sądu. Taka sytuacja miała miejsce na przykład w 2012 r., kiedy Minister Sprawiedliwości zniósł 79 sądów rejonowych, w wyniku czego na inne miejsce służbowe, bez zgody zainteresowanych, przeniesiono około 500 sędziów.

Nieuwzględniony wniosek o przeniesienie na inne miejsce służbowe sędzia może po raz kolejny złożyć Ministrowi nie wcześniej niż po upływie 3 lat, chyba że przyczyną nieuwzględnienia wniosku był jedynie brak wystarczającej liczby wolnych stanowisk sędziowskich w odniesieniu do liczby wniosków. Sędzia może wnioskować o przeniesienie na to samo miejsce służbowe, co poprzednio, bądź na inne miejsce służbowe, co poprzednio. Wniosek złożony przed upływem terminu 3 lat pozostaje bez rozpoznania. Minister Sprawiedliwości może z urzędu zwrócić się do sędziego, który poprzednio składał wniosek o przeniesienie na inne miejsce służbowe, o wyrażenie zgody na przeniesienie na wnioskowane lub inne miejsce służbowe.

Przeniesienie na inne miejsce służbowe obejmuje tak sędziego, jak i asesora sądowego. Podobnie jak wobec sędziego, przeniesienie asesora sądowego na inne miejsce służbowe następuje na jego wniosek. Może do niego dojść w szczególnie uzasadnionych przypadkach, a zarazem nie wcześniej niż po dwóch latach od dnia mianowania. Wyjątkowo (podobnie jak w przypadku sędziów) przeniesienie asesora sądowego na inne miejsce służbowe może nastąpić bez jego zgody. Dzieje się tak w przypadku zniesienia stanowiska spowodowanego zmianą w organizacji sądownictwa lub zniesieniem danego sądu lub wydziału zamiejscowego albo przeniesieniem siedziby sądu. Przeniesienie bez zgody asesora sądowego następuje również ze względu na wyrażony w art. 6 Prawa o ustroju sądów powszechnych zakaz pracy w tym samym wydziale sądu sędziów, asesorów sądowych albo referendarzy sądowych pozostających ze sobą w stosunku pokrewieństwa w linii prostej lub powinowactwa w linii prostej albo w stosunku przysposobienia, małżonkowie oraz gdy są rodzeństwem. Na wzór regulacji obejmującej sędziego, zgoda asesora sądowego na przeniesienie na inne miejsce służbowe nie jest potrzebna, gdy wymaga tego wzgląd na powagę stanowiska. W tym przypadku przenie- 
sienie następuje na podstawie orzeczenia sądu dyscyplinarnego, wydanego na wniosek kolegium właściwego sądu lub Krajowej Rady Sądownictwa. Zgody osoby objętej przeniesieniem nie wymaga również przeniesienie w wyniku kary dyscyplinarnej ${ }^{12}$.

Podobnie jak w przypadku sędziów, decyzję o przeniesieniu asesora sądowego na inne miejsce służbowe wydaje Minister Sprawiedliwości. W dwóch przypadkach od decyzji Ministra Sprawiedliwości przysługuje asesorowi sądowemu środek prawny w postaci odwołania do Sądu Najwyższego. Ma on prawo zaskarżyć decyzję Ministra po pierwsze, gdy przeniesienie na inne miejsce służbowe nastąpiło w przypadku zniesienia stanowiska asesora sądowego wywołanego zmianą w organizacji sądownictwa lub zniesieniem danego sądu lub wydziału zamiejscowego albo przeniesieniem siedziby sądu. Druga sytuacja, gdy dopuszczalne jest zaskarżenie decyzji Ministra Sprawiedliwości, to przeniesienie asesora sądowego na inne stanowisko służbowe ze względu na niedopuszczalność zajmowania stanowiska asesora sądowego w danym sądzie ze względu na zakaz pracy w tym samym wydziale sądu sędziów, asesorów sądowych albo referendarzy sądowych pozostających ze sobą w stosunku pokrewieństwa $\mathrm{w}$ linii prostej lub powinowactwa w linii prostej albo w stosunku przysposobienia, małżonkowie oraz gdy są rodzeństwem.

Od przeniesienia sędziego przez Ministra Sprawiedliwości na inne miejsce służbowe ustawodawca odróżnia delegowanie sędziego na inne miejsce służbowe. Delegowanie sędziego jest aktem kierownictwa wewnętrznego z zakresu administracji sądowej, mającym na celu realizowanie polityki kadrowej w wymiarze sprawiedliwości ${ }^{13}$. Decyzję w sprawie przeniesienia sędziego na inne miejsce służbowe, jak też w sprawie jego delegowania, podejmuje Minister Sprawiedliwości. W odróżnieniu od przeniesienia, delegowanie sędziego odbywa się wyłącznie na jego wniosek, co ma mieć znaczenie gwarancyjne z punktu widzenia zachowania stabilności pełnionej służby przez sędziego, stabilności służby traktowanej jako jedna z gwarancji niezawisłości sędziowskiej.

Minister może delegować sędziego, za jego zgodą, do pełnienia obowiązków sędziego lub czynności administracyjnych w innym sądzie równorzędnym

12 Szerzej na ten temat zob. E. Gudowska-Natanek, Formalne prawo odpowiedzialności dyscyplinarnej sędziów sądów powszechnych, „Przegląd Prawa Konstytucyjnego” 2018, nr 1.

13 A. Machnikowska, op.cit., s. 330. 
lub niższym. W przypadku delegowania sędziego do sądu równorzędnego, przysługuje mu dodatek funkcyjny wizytatora sądu okręgowego. W szczególnie uzasadnionych wypadkach delegowanie może nastąpić do sądu wyższego i nie ma w tym zakresie ograniczeń, co oznacza, że nie musi to być jedynie sąd bezpośrednio wyższy, ale że dopuszczalne jest (i taka też jest praktyka) delegowanie sędziego $\mathrm{z}$ sądu rejonowego do sądu apelacyjnego. U podstaw decyzji Ministra o delegowaniu sędziego do innego sądu leżą racjonalne wykorzystanie kadr sędziowskich oraz potrzeby wynikające z obciążenia zadaniami poszczególnych sądów. O spełnieniu tych przesłanek przesądza wola Ministra.

Delegowanie może nastąpić do Ministerstwa Sprawiedliwości lub innej jednostki organizacyjnej podległej Ministrowi Sprawiedliwości albo przez niego nadzorowanej; Kancelarii Prezydenta Rzeczypospolitej Polskiej (na wniosek Prezydenta Rzeczypospolitej Polskiej); Ministerstwa Spraw Zagranicznych (na wniosek ministra właściwego do spraw zagranicznych); Sądu Najwyższego (na wniosek Pierwszego Prezesa Sądu Najwyższego albo Prezesa Sądu Najwyższego kierującego pracą Izby Dyscyplinarnej w odniesieniu do sędziów delegowanych do tej izby); sądu administracyjnego (na wniosek Prezesa Naczelnego Sądu Administracyjnego). Delegowanie odbywa się na czas określony, nie dłuższy niż 2 lata, albo na czas nieokreślony.

Minister Sprawiedliwości może delegować sędziego, za jego zgodą (na wniosek Przewodniczącego Krajowej Rady Sądownictwa) do pełnienia czynności w Biurze tej Rady. Władny jest delegować sędziego, za jego zgodą, do pełnienia czynności lub prowadzenia zajęć szkoleniowych w Krajowej Szkole Sądownictwa i Prokuratury.

Delegowanie sędziego do organu innego niż sąd i wynikająca $\mathrm{z}$ tego jego podległość organizacyjna kierownikowi danej jednostki organizacyjnej jest w kolizji z zasadą podziału władz (art. 10 Konstytucji RP). Oznacza przemieszanie władzy sądowniczej z administracyjną. Jest też w kolizji z zasadą niezawisłości sędziego, gdyż powoduje podległość organizacyjną sędziego kierownikowi jednostki organizacyjnej, do której sędzia został delegowany. Osoba formalnie zachowuje status niezawisłego sędziego, a jednocześnie wykonując czynności urzędnicze - materialnie działa w ramach urzędniczej nadrzędności - podległości, będącej nie do pogodzenia z sędziowską niezawisłością. W celu minimalizowania negatywnych konsekwencji występujących kolizji, ustawodawca wprowadził zakaz łączenia przez sędziego funkcji 
orzekania z pełnieniem czynności administracyjnych w Ministerstwie Sprawiedliwości lub innej jednostce organizacyjnej podległej Ministrowi Sprawiedliwości, Kancelarii Prezydenta Rzeczypospolitej Polskiej albo Ministerstwie Spraw Zagranicznych. W efekcie powierzania sędziom wykonywania czynności administracyjnych doszło do wykształcenia nietypowej konstrukcji prawnej: sędziego nieorzekającego.

Minister Sprawiedliwości może delegować sędziego (na jego wniosek) do wykonywania obowiązków w międzynarodowej sędziowskiej organizacji pozarządowej. Jest kompetentny delegować sędziego (za jego zgodą) do pełnienia obowiązków lub pełnienia określonej funkcji poza granicami państwa w ramach działań podejmowanych przez organizacje międzynarodowe lub ponadnarodowe oraz zespoły międzynarodowe, które działają na podstawie ratyfikowanych umów międzynarodowych, w tym umów konstytuujących organizacje międzynarodowe. Takie delegowanie może odbyć się zgodnie z kwalifikacjami sędziego, na czas określony, nie dłuższy niż cztery lata, z możliwością ponownego delegowania na kolejny okres, nieprzekraczający czterech lat.

$\mathrm{Na}$ wniosek Dyrektora Krajowej Szkoły Sądownictwa i Prokuratury, Minister Sprawiedliwości może delegować sędziego (za jego zgodą) do pełnienia obowiązków lub określonej funkcji, lub odbycia stażu trwającego dłużej niż miesiąc, poza granicami państwa w ramach współpracy międzynarodowej Krajowej Szkoły Sądownictwa i Prokuratury. Delegowanie odbywa się zgodnie z kwalifikacjami sędziego, na czas określony. Nie może być on dłuższy niż cztery lata, z możliwością ponownego delegowania na kolejny okres nieprzekraczający czterech lat.

Sędzia delegowany do pełnienia czynności administracyjnych w Ministerstwie Sprawiedliwości, Kancelarii Prezydenta Rzeczypospolitej Polskiej, urzędzie obsługującym ministra właściwego do spraw zagranicznych albo Krajowej Szkole Sądownictwa i Prokuratury, jak również do prowadzenia zajęć szkoleniowych w Krajowej Szkole Sądownictwa i Prokuratury pobiera wynagrodzenie zasadnicze przysługujące mu na zajmowanym stanowisku sędziowskim oraz dodatek za długoletnią pracę. W okresie delegowania sędzia otrzymuje także dodatek funkcyjny.

W okresie delegowania, ze względu na charakter pracy i zakres wykonywanych zadań, Minister Sprawiedliwości może przyznać sędziemu dodatek specjalny w wysokości nieprzekraczającej łącznie 40\% wynagrodze- 
nia zasadniczego i dodatku funkcyjnego. Co do zasady, Minister przyznaje dodatek na czas określony, ale w indywidualnych przypadkach - także na czas nieokreślony ${ }^{14}$. W szczególnie uzasadnionych przypadkach Minister Sprawiedliwości jest kompetentny przyznać dodatek specjalny w wyższej wysokości niż 40\% wynagrodzenia zasadniczego i dodatku funkcyjnego sędziego. Delegowanie sprzyja zatem nadzwyczajnemu wzbogaceniu sędziego nieorzekającego.

Sędziemu delegowanemu do pełnienia obowiązków lub funkcji za granicą przysługuje dodatek zagraniczny na pokrycie zwiększonych kosztów związanych z pełnieniem obowiązków lub funkcji poza granicami państwa. Jest on ustalany adekwatnie do warunków i zakresu ich pełnienia.

W przypadku powierzenia sędziemu pełnienia obowiązków lub funkcji wiążących się ze zmianę miejsca pobytu trwającą co najmniej rok otrzymuje on jednorazowy dodatek adaptacyjny. W takiej sytuacji ma miejsce pokrycie kosztów podróży przesiedleniowej sędziego delegowanego i każdego przenoszącego się z nim członka rodziny, w tym przewozu ich mienia, niezależnie od terminów ich faktycznego przesiedlenia. Raz na dwa lata ma miejsce pokrycie kosztów przejazdu sędziego delegowanego oraz członków jego rodziny przebywających z nim na stałe poza granicami państwa, z miejsca delegacji do miejsca stałego zamieszkania na urlop wypoczynkowy i z powrotem. Zwraca się koszty podróży w związku z rozpoczęciem i zakończeniem pełnienia obowiązków lub funkcji poza granicami państwa, podróży służbowej na terytorium obcego państwa poza miejscem delegowania, przejazdu $\mathrm{z}$ miejsca delegowania do kraju i z powrotem w uzasadnionych przypadkach służbowych lub losowych. Zwraca się koszty leczenia, gdy delegacja sędziego następuje do państwa niebędącego członkiem Unii Europejskiej. Do wysokości udokumentowanych wydatków, nieprzekraczających wysokości ustalonego limitu, pokrywa się sędziemu koszty zamieszkania w miejscu delegacji.

Tak jak Minister kompetentny jest delegować sędziego, tak też kompetentny jest odwołać sędziego z delegacji, w tym - ze skutkiem natychmiastowym. Motyw odwołania ma charakter wolicjonalny. Nie musi wiązać się $\mathrm{z}$ formalnoprawną rozliczalnością sędziego z jakości podejmowanych przez

14 Dodatek dla sędziów delegowanych do Kancelarii Prezydenta Rzeczypospolitej Polskiej oraz urzędu obsługującego Ministra Spraw Zagranicznych może być przyznany, na wniosek Prezydenta Rzeczypospolitej Polskiej albo Ministra Spraw Zagranicznych. 
niego czynności. Może być wynikiem niesformalizowanej oceny działalności sędziego. W związku z powyższym nie można wykluczyć sytuacji, że tak jak delegowanie może być formą nagrody dla sędziego, którego działalność Minister docenia, tak też jego odwołanie z delegacji może być traktowane jako swego rodzaju kara dla sędziego, który zawiódł zaufanie Ministra. W ten sposób organ władzy wykonawczej odpowiednio nagradza bądź karze sędziego za jego działalność wykonywaną w ramach urzędu sędziego, co jest w kolizji z zasadą niezawisłości sędziego.

Zmiana miejsca służbowego sędziego lub delegowanie do innego sądu, jak też zakończenie delegowania, nie powinny negatywnie wpływać na sprawy rozstrzygane z udziałem sędziego. Nie są bowiem przeszkodą do podejmowania czynności w sprawach przydzielonych w dotychczasowym miejscu służbowym albo miejscu pełnienia służby, aż do ich zakończenia. Od tej reguły przewidziane są dwa wyjątki. Od rozpoznania spraw przyporządkowanych w czasie delegacji sędzia może być zwolniony na wniesiony przez niego wniosek. W drugim przypadku, od rozpoznania spraw przyporządkowanych w czasie delegacji sędzia może być zwolniony decyzją kolegium sądu miejsca delegowania sędziego. Przy tym kolegium sądu powinno kierować się w szczególności znaczną odległością między sądem macierzystym, a sądem, do którego sędzia jest delegowany, jak również stopniem zaawansowania rozpoznawanych spraw.

W świetle przeprowadzonego wywodu, przenoszenie oraz delegowanie sędziów i asesorów sądów powszechnych nie musi być zdarzeniem neutralnym z punktu widzenia ich niezawisłości ${ }^{15}$, wzmacniającym zaufanie do sądów. Zawiera w sobie natomiast istotne ryzyka w tym zakresie. Sprawia, że od zgody Ministra Sprawiedliwości jako organu władzy sensu stricto politycznej, może zależeć przebieg kariery zawodowej sędziego, w szczególności sędziego, który chce awansować. To Minister decyduje o przeniesieniu sędziego na inne miejsce służbowe, o jego delegowaniu do pełnienia obowiązków sędziego lub czynności administracyjnych w innym sądzie lub w innej jednostce organizacyjnej i związanym z tym podniesieniem statusu nie tylko zawodowego, ale również materialnego sędziego.

15 Pomijam przy tym motyw niezawisłości asesora sądowego, który sam w sobie jest ustrojowo problematyczny. 
Są to okoliczności istotne z punktu widzenia niezawisłości sędziowskiej, a przy tym mogące negatywnie na nią wpływać. Mogą eksponować i nadawać znaczenia typowo ludzkim ambicjom, których nie są pozbawieni sędziowie, jak żądza awansowania, wykonywania bardziej prestiżowych zadań czy wzrostu pozycji materialnej. Prawne dowartościowanie tego typu cech sędziów jest ryzykiem dla jakości pełnienia funkcji sędziowskich. Wykoślawia słabsze charaktery, stwarza pożywkę dla serwilizmu i jako takie, w przypadku przenoszeń powinno zostać zredukowane (do sytuacji, gdy przeniesienie jest wywołane zmianą organizacji sądów, na którą sędzia nie ma wpływu), a w przypadku delegowania - uchylone.

\section{Literatura}

Gudowska-Natanek E., Formalne prawo odpowiedzialności dyscyplinarnej sędziów sadów powszechnych, „Przegląd Prawa Konstytucyjnego” 2018, nr 1.

Kozielewicz W., Instytucja delegowania sędziego do petnienia obowiązków sędziego w innym sadzie - aspekty ustrojowe i procesowe, [w:] Rzetelny proces karny. Księga jubileuszowa Profesor Zofii Świdy, red. J. Skorupka, Warszawa 2009.

Ławnikowicz G., Z rozważań nad polskim autorytaryzmem. Pewność stanowiska sędziego w Konstytucji kwietniowej, „Annales Universitatis Mariae Curie Skłodowska Lublin - Polonia” 2019, Sectio G, vol. LXVI, 1.

Machnikowska A., O niezawisłości sędziów i niezależności sądów w trudnych czasach. Wymiar sprawiedliwości w pułapce sprawności, Warszawa 2018.

Mazurkiewicz M., Problem zwierzchniego nadzoru nad działalnością administracyjną sq̨dów na tle konstytucyjnych gwarancji niezależności sądów i niezawisłości sędziów, [w:] Transformacja systemów wymiaru sprawiedliwości. Tom I. Pozycja ustrojowa władzy sądowniczej i uwarunkowania transformacji, red. J. Jaskiernia, Toruń 2011.

Rakowska-Trela A., Sądy i sędziowie wobec niedemokratycznych przemian, „Studia Politologiczne" 2018, vol. 47.

Systemy rządów w perspektywie porównawczej, red. J. Szymanek, Warszawa 2014. 